\title{
Effect of FYM, NPK and Biofertilizers on Flowering, Fruit Yield and Quality of Kinnow
}

\author{
Rawat Mandeep*, Deepanshu and Wilson Deena \\ Department of Horticulture, Sam Higginbottom University of Agriculture, \\ Technology and Sciences, Prayagraj - 211007, India \\ *Corresponding author
}

\section{Keywords}

Kinnow, FYM, Azotobacter, Azospirillum, PSB (Phosphorus Solublizing Bacteria)

\section{Article Info}

Accepted: 04 August 2020 Available Online: 10 September 2020
A study was made on the application of different levels of FYM, NPK along with biofertilizers on Kinnow in order to check its effect on flowering, fruiting and fruit yield. The present study was carried out during February 2019 to December 2019 in Central horticulture research farm of Department of Horticulture, SHUATS, Prayagraj. The study was conducted in Randomized Block Design with 11 treatments replicated thrice. The treatments were $\mathrm{T}_{0}$ Control (500: 250: $500 \mathrm{~g} \mathrm{~N}, \mathrm{P}, \mathrm{K} /$ tree/ year) , $\mathrm{T}_{1}(70 \%$ $\mathrm{NPK} /$ tree $+27 \mathrm{~kg} \mathrm{FYM} /$ tree $), \mathrm{T}_{2}(70 \% \mathrm{NPK} /$ tree $+27 \mathrm{~kg} \mathrm{FYM} /$ tree + Azotobacter $10 \mathrm{~g} /$ tree), $\mathrm{T}_{3}(70 \% \mathrm{NPK} /$ tree $+27 \mathrm{~kg} \mathrm{FYM} /$ tree + Azospirillum $10 \mathrm{~g} /$ tree), $\mathrm{T}_{4}(70 \% \mathrm{NPK} /$ tree $+27 \mathrm{~kg}$ FYM $/$ tree $+\mathrm{PSB}$ $10 \mathrm{~g} /$ tree $), \mathrm{T}_{5}(70 \% \mathrm{NPK} /$ tree $+27 \mathrm{~kg} \mathrm{FYM} /$ tree + Azotobacter $10 \mathrm{~g} /$ tree + Azospirillum $10 \mathrm{~g} /$ tree + PSB $10 \mathrm{~g} /$ tree $), \mathrm{T}_{6}(60 \% \mathrm{NPK} /$ tree $+30 \mathrm{~kg} \mathrm{FYM} /$ tree $), \mathrm{T}_{7}(60 \% \mathrm{NPK} /$ tree $+30 \mathrm{~kg} \mathrm{FYM} /$ tree + Azotobacter $15 \mathrm{~g} /$ tree $), \mathrm{T}_{8}$ $(60 \%$ NPK $/$ tree $+30 \mathrm{~kg}$ FYM/ tree + Azospirillum $15 \mathrm{~g} /$ tree $), \mathrm{T}_{9}(60 \% \mathrm{NPK}$ $/$ tree $+30 \mathrm{~kg}$ FYM/ tree + PSB 30g/ tree), $\mathrm{T}_{10}(60 \% \mathrm{NPK} /$ tree $+30 \mathrm{~kg}$ FYM/ tree + Azotobacter $15 \mathrm{~g}$ / tree + Azospirillium $15 \mathrm{~g} /$ tree + PSB $15 \mathrm{~g} /$ tree). Out of the above treatments, plants which were supplemented according to treatment $\mathrm{T}_{5}(70 \% \mathrm{NPK} /$ tree $+27 \mathrm{~kg}$ FYM / tree + Azotobacter $10 \mathrm{~g} /$ tree + Azospirillum $10 \mathrm{~g}$ / tree + PSB $10 \mathrm{~g} /$ tree) showed the superior result in terms of plant height, plant spread, no. of flowers, average fruit weight, fruit yield per plant, weight of pulp, weight of peel, pulp to peel ratio, T.S.S. and Titratable Acidity. 


\section{Introduction}

Citrus is a widely growing fruit crop of tropical and sub-tropical countries with a global production of 6.3 million MT (USDA report July 2019) and their production is confined between $0-40^{\circ} \mathrm{N}$ and $\mathrm{S}$ of equator. India ranks $6^{\text {th }}$ in citrus fruit production with an area of 1003 ha along with the production of 12546 MT (NHB Database, 2018). The genus Citrus consists of wide variation in its species ranging from sweet orange, lemon, lime, grape fruit, mandarins etc. It is a fruit belongs to the family Rutaceae and subfamily Aurantioideae with a chromosome number of 2n= 18 (Kurg 1943).

Kinnow, a King-willow leaf mandarin was the resultant of an interspecific hybridization between (Citrus nobilis Loureiro $\mathrm{x}$ Citrus deliciosa Tenore) carried out first time by H.B. Frost in 1915, at the University of California Citrus Experiment Station and commercially released in 1935 as a new citrus hybrid. Kinnow as a fruit crop is highly nutrient receptive and requires all major 17 nutrients for a good crop production. Adequate supply of nitrogen, phosphorus and potassium are important for citrus tree growth and productivity (Quaggio et al., 2002). Nitrogen is invoked as "wheel balance" of citrus nutrition, because of the fact that the efficiency of other nutrients based on it. It imparts dark green colour and glossiness to leaves. Sharma and Chopra (2000) observed that nitrogen played an important role in increasing the growth and yield of sweet orange. Potassium is necessary for to carry out physiological functions in plants such as translocation of sugars, synthesis of proteins and cell division and growth. . It also intensifies the competence of plants to fight against disease, insect, pest attacks, cold, drought and other distinct conditions. It rectifies the water economy of trees and generally increases citrus yield, not in the number, but in fruit size. Phosphorus is indispensable for many processes of life such as photosynthesis, synthesis and breakdown of carbohydrates and the transfer of energy within the plant. Farm yard manure (FYM) provides organic matter and crucial plant nutrients to the plant's rhizosphere. FYM also enhances soil porosity and water holding capacity of the soil. The application of FYM has been reported to enhance the availability of native as well as applied P. It was also reported that organic matter plays an important role for the retention of urea and greater uptake of $\mathrm{P}$ and $\mathrm{K}$.

Use of inorganic fertilizers along with organic manures and bio-fertilizers is a proven technology to build up the fertility status of the soil (Srivastava and Ngullie 2009, Srivastava and Singh 2009).

Bio-fertilizers are the natural fertilizers that are microbial inoculants of bacteria, algae or fungi alone or in combination (kumar et al., 2017). Azotobacter and Azospirillum these are free-living atmosphere nitrogen fixing bacteria. They fix atmospheric nitrogen in cereal crops and do not need a particular host. Azotobacter, a free living microbe, acts as plant growth promoting rhizobacteria (PGPR) in the rhizosphere of almost all crops (Gomare et al., 2013). Azotobacter produces many growth regulators such as IAA and GA which positively influence plant growth (Sharma and Kumar 2008). They can fix 15$20 \mathrm{~kg} / \mathrm{ha} \mathrm{N}$ per year. Azotobacter $s p$. can also give rise to antifungal substances to prevent against many plant pathogens. Phosphorus solubilizing bacteria (PSB) under acidic or calcareous, large amounts of phosphorus can be fixed in the soil but may be unavailable to the plants. Phosphobacterins mainly consists of microbs like bacteria and fungi which can make insoluble forms of phosphorus available to the plants, the solublizing effect of these phosphobacterins are generally due to the 
production of organic acids that lower the $\mathrm{pH}$ of soil and bring about the disintegration of bound forms of phosphate. It is reported that PSB culture helps to increase yield up to 200$500 \mathrm{~kg} / \mathrm{ha}$ and thus 30 to $50 \mathrm{~kg}$ of superphosphate can be saved (Chen, 2006).

\section{Materials and Methods}

The study was conducted in Randomized Block Design with 11 treatments replicated thrice.

The treatments were $\mathrm{T}_{0}$ Control (500: 250: $500 \mathrm{~g} \mathrm{~N}, \mathrm{P}, \mathrm{K} /$ tree/ year), $\mathrm{T}_{1}(70 \% \mathrm{NPK} /$ tree $+27 \mathrm{~kg}$ FYM / tree $), \mathrm{T}_{2}(70 \% \mathrm{NPK} /$ tree + $27 \mathrm{~kg}$ FYM / tree + Azotobacter $10 \mathrm{~g} /$ tree), $\mathrm{T}_{3}$ $(70 \% \mathrm{NPK} /$ tree $+27 \mathrm{~kg} \mathrm{FYM} /$ tree + Azospirillum 10g/ tree), $\mathrm{T}_{4}(70 \% \mathrm{NPK} /$ tree $+27 \mathrm{~kg}$ FYM / tree + PSB 10g/tree), $\mathrm{T}_{5}(70 \%$ $\mathrm{NPK} /$ tree $+27 \mathrm{~kg}$ FYM / tree + Azotobacter $10 \mathrm{~g} /$ tree + Azospirillum 10g/ tree + PSB 10g/ tree), $\mathrm{T}_{6}(60 \% \mathrm{NPK} /$ tree $+30 \mathrm{~kg}$ FYM / tree $)$, $\mathrm{T}_{7}(60 \% \mathrm{NPK} /$ tree $+30 \mathrm{~kg} \mathrm{FYM} /$ tree + Azotobacter $15 \mathrm{~g} /$ tree), $\mathrm{T}_{8}(60 \% \mathrm{NPK} /$ tree + 30kg FYM/ tree + Azospirillum $15 \mathrm{~g} /$ tree), $\mathrm{T}_{9}$ $(60 \% \mathrm{NPK} /$ tree $+30 \mathrm{~kg}$ FYM/ tree + PSB $30 \mathrm{~g} /$ tree $), \mathrm{T}_{10}(60 \% \mathrm{NPK} /$ tree $+30 \mathrm{~kg}$ FYM/ tree + Azotobacter $15 \mathrm{~g} /$ tree + Azospirillium $15 \mathrm{~g} /$ tree + PSB $15 \mathrm{~g} /$ tree) .

\section{Climatic condition in the experimental site}

The area of Prayagraj district comes under sub-tropical belt in the south east of Uttar Pradesh, which experience extremely hot summer and fairly cold winter.

The maximum temperature of the location reaches up to $46^{\circ} \mathrm{C}-48^{\circ} \mathrm{C}$ and seldom falls as low as $4^{\circ} \mathrm{C}-5^{\circ} \mathrm{C}$. The relative humidity ranges between 20 to $94 \%$. The average rainfall in this area is around $1013.4 \mathrm{~mm}$ annually. However, occasional precipitation is also not uncommon during winter months.

\section{Results and Discussion}

The result of the experiment entitled "Effect of FYM, NPK and biofertilizers on flowering, fruit yield and quality of kinnow" was carried out during February to December in the, Department of Horticulture, Sam Higginbottom University of Agriculture, Technology \& Sciences Prayagraj. The results of the investigation regarding the Growth and yield of 5 yrs old Kinnow trees as influence by different levels of FYM, NPK and biofertilizers on growth and yield of Kinnow have been presented in tables and figures, wherever required.

The data in the table 1 showed that the plant height and the plant spread are significantly affected by bio-fertilizer in combination with FYM and NPK.

The highest value plant height and plant spread is recorded in $T_{5}$ followed by $T_{10}$. Same as in case of number of flowers, average fruit weight, pulp weight, pulp to peel ratio and yield, $\mathrm{T}_{5}$ is recorded to with the highest values followed by $T_{10}$. The lowest values were recorded with $\mathrm{T}_{0}$.

From the previously mentioned results, it was clear the main role of FYM and bio-fertilizers along with different doses of NPK on Kinnow trees, for supply nutrients in order to bring renovation in growth and quality. As the treatment $\mathrm{T}_{5}(70 \% \mathrm{NPK} /$ tree $+27 \mathrm{~kg} \mathrm{FYM} /$ tree + Azotobacter 10g/ tree + Azospirillum $10 \mathrm{~g} /$ tree + PSB 10g/ tree) showed the best result with respect to yield an quality of fruits. Therefore, this treatment is recommended $\mathrm{T}_{5}$ (70\% NPK / tree $+27 \mathrm{~kg}$ FYM / tree + Azotobacter $10 \mathrm{~g}$ / tree + Azospirillum $10 \mathrm{~g} /$ tree + PSB 10g/ tree). 
Table.1 Effect of different treatments on plant height and plant spread of Kinnow

\begin{tabular}{|c|c|c|c|c|c|c|c|c|c|c|c|}
\hline \multirow[t]{2}{*}{ S.No. } & \multirow[t]{2}{*}{ Treatments } & \multicolumn{5}{|c|}{ Plant height } & \multicolumn{5}{|c|}{ Plant spread } \\
\hline & & 45 days & 90 days & 135 days & 180 days & 225 days & 45 days & 90 days & 135 days & 180 days & 225 days \\
\hline 1. & $\mathrm{~T}_{0}$ & 216.000 & 218.667 & 221.667 & 224.333 & 227.667 & 150.47 & 156.15 & 163.27 & 167.913 & 172.413 \\
\hline 2. & $\mathrm{~T}_{1}$ & 237.333 & 240.333 & 243.333 & 246.333 & 249.333 & 162.08 & 167.093 & 171.563 & 175.51 & 179.76 \\
\hline 3. & $\mathrm{~T}_{2}$ & 261.000 & 264.333 & 267.667 & 270.667 & 273.333 & 172.067 & 180.627 & 185.15 & 189.65 & 195.35 \\
\hline 4. & $\mathrm{~T}_{3}$ & 266.667 & 269.000 & 271.667 & 274.667 & 277.333 & 178.46 & 186.057 & 193.12 & 196.213 & 201.177 \\
\hline 5. & $\mathrm{~T}_{4}$ & 275.000 & 277.333 & 279.667 & 282.667 & 285.333 & 173.783 & 178.373 & 182.953 & 187.783 & 192.04 \\
\hline 6. & $\mathrm{~T}_{5}$ & 307.667 & 311.000 & 313.333 & 316.333 & 319.333 & 230.667 & 239.847 & 246.667 & 250.623 & 256.127 \\
\hline 7. & $\mathrm{~T}_{6}$ & 286.667 & 289.333 & 291.667 & 294.333 & 297 & 158.3 & 164.21 & 168.193 & 174.537 & 179.63 \\
\hline 8. & $\mathrm{~T}_{7}$ & 248.667 & 251.333 & 254.000 & 257 & 259.667 & 173.813 & 177.923 & 183.137 & 186.783 & 190.82 \\
\hline 9. & $\mathrm{~T}_{8}$ & 281.667 & 283.667 & 286.333 & 289.333 & 295.667 & 169.953 & 174.54 & 179.433 & 183.867 & 189.107 \\
\hline 10. & $\mathrm{~T}_{9}$ & 264.000 & 266.667 & 269.667 & 272.333 & 275 & 171.55 & 175.4 & 180.643 & 188.61 & 194.443 \\
\hline \multirow[t]{5}{*}{11.} & $\mathrm{~T}_{10}$ & 294.667 & 297.333 & 303.667 & 306.667 & 309.333 & 204.8 & 209.547 & 216.547 & 220.213 & 225.347 \\
\hline & F-ratio & $\mathrm{S}$ & $\mathrm{S}$ & $\mathrm{S}$ & $\mathrm{S}$ & $\mathrm{S}$ & $\mathrm{S}$ & $\mathrm{S}$ & $\mathrm{S}$ & $\mathrm{S}$ & $\mathrm{S}$ \\
\hline & C.D. & 6.499 & 6.909 & 7.161 & 6.722 & 6.066 & 15.916 & 15.048 & 15.196 & 16.073 & 15.819 \\
\hline & S.E(d) & 3.094 & 3.289 & 3.409 & 3.2 & 2.888 & 7.577 & 7.163 & 7.234 & 7.652 & 7.531 \\
\hline & C.V & 1.418 & 1.492 & 1.529 & 1.421 & 1.268 & 5.245 & 4.802 & 4.706 & 4.859 & 4.662 \\
\hline
\end{tabular}


Table.2 Effect of different treatments on no. of flowers, no. of fruits per plant, yield of fruit/ tree, fruit weight, pulp weight, peel weight, pupl to peel ratio, T.S.S and titratable acidity of kinnow

\begin{tabular}{|c|c|c|c|c|c|c|c|c|c|}
\hline S.No. & Treatments & $\begin{array}{l}\text { No. of } \\
\text { flowers }\end{array}$ & $\begin{array}{c}\text { Yield of } \\
\text { fruits /tree }\end{array}$ & $\begin{array}{c}\text { Fruit } \\
\text { weight }\end{array}$ & $\begin{array}{c}\text { Pulp } \\
\text { weight }\end{array}$ & $\begin{array}{c}\text { Peel } \\
\text { weight }\end{array}$ & $\begin{array}{c}\text { Pulp to } \\
\text { peel } \\
\text { ratio }\end{array}$ & T.S.S & $\begin{array}{c}\text { Titrtable } \\
\text { acidity }\end{array}$ \\
\hline 1. & $\mathrm{~T}_{0}$ & 58.333 & $3,759.267$ & 95.000 & 62.033 & 30.533 & 2 & 5.7 & 0.95 \\
\hline 2. & $\mathrm{~T}_{1}$ & 98.333 & $7,067.000$ & 123.367 & 99.367 & 25.633 & 3.833 & 6.8 & 0.54 \\
\hline 3. & $\mathrm{~T}_{2}$ & 121 & $8,183.966$ & 134.900 & 103.767 & 28.6 & 3.6 & 8.467 & 0.713 \\
\hline 4. & $\mathrm{~T}_{3}$ & 94.667 & $8,641.233$ & 138.800 & 109.967 & 29.3 & 3.733 & 8.067 & 0.807 \\
\hline 5. & $\mathrm{~T}_{4}$ & 113.333 & $9,111.866$ & 145.400 & 118.6 & 21.567 & 5.467 & 8.6 & 0.78 \\
\hline 6. & $\mathrm{~T}_{5}$ & 149 & $17,536.630$ & 154.633 & 160.92 & 15.9 & 10.167 & 10.833 & 0.287 \\
\hline 7. & $\mathrm{~T}_{6}$ & 140.667 & $11,075.000$ & 193.567 & 123.867 & 27.2 & 4.4 & 7.867 & 0.7 \\
\hline 8. & $\mathrm{~T}_{7}$ & 133.667 & $9,982.800$ & 135.533 & 105.067 & 26.233 & 3.933 & 6.633 & 0.813 \\
\hline 9. & $\mathrm{~T}_{8}$ & 141.667 & $10,832.870$ & 164.800 & 132.633 & 28.7 & 4.6 & 8.067 & 0.607 \\
\hline 10. & $\mathrm{~T}_{9}$ & 144 & $10,977.600$ & 144.600 & 112.967 & 28 & 4 & 8.4 & 0.67 \\
\hline \multirow[t]{5}{*}{11.} & $\mathrm{~T}_{10}$ & 147.333 & $14,061.000$ & 173.700 & 142.967 & 18.533 & 7.7 & 9.9 & 0.403 \\
\hline & C.D & 17.053 & $2,030.427$ & 5.5 & 5.333 & 3.033 & 0.704 & 0.771 & 0.069 \\
\hline & S.E(d) & 8.118 & 969.525 & 2.618 & 2.539 & 1.444 & 0.335 & 0.367 & 0.033 \\
\hline & F-ratio & S & S & S & $\mathrm{S}$ & S & $\mathrm{S}$ & $\mathrm{S}$ & $\mathrm{S}$ \\
\hline & C.V & 8.149 & 11.707 & 2.199 & 2.688 & 6.492 & 8.445 & 5.536 & 6.045 \\
\hline
\end{tabular}




\section{References}

Chen Jen-Hshuan (2006). Internat. Workshop on sustained management of the soilrhizosphere system for efficient crop production and fertilizer use at land development department Bangkok Thailand 1-11.

Gomare K S, Mese M and Shetkar Y. 2013. Isolation of Azotobacter and cost effective production of biofertilizer. Biotechnology 3(5): 54-6.

Kumar R, Kumawat N and Sahu K. Y. 2017 Role of Biofertilizer in Agriculture. Popular Kheti Vol.5 2321-0001.

Quaggio, J.A; D. Mattos and H. Cantarella; E.L.E. Almeida and S.A.B. Cardoso (2002). Lemon yield and fruit quality affected by NPK fertilization. Scientia
Horticulture 96:151-162.

Sharma KL, Chopra SK 2000. Effect of nitrogen, phosphorus and potasf on the growth and yield of blood red sweet orange (Citrus sinensis Osbeck) if grown in foot hills and valley areas of Himachal Pradesh. Punjab Horticulture Journal. 40:19-23.

Sharma S D and Kumar P. 2008. Relationship of arbuscular mycorrhizal fungi and Azotobacter with plant growth, fruit yield, soil and leaf nutrient status of mango orchards in North-Western Himalayan region of India. Journal of Applied Horticulture 10(2): 172-8.

Srivastava A K and Ngullie E. 2009. Integrated nutrient management: Theory and practice. Dynamic Soil, Dynamic Plant 3(1): 1-30.

\section{How to cite this article:}

Rawat Mandeep, Deepanshu and Wilson Deena. 2020. Effect of FYM, NPK and Biofertilizers on Flowering, Fruit Yield and Quality of Kinnow. Int.J.Curr.Microbiol.App.Sci. 9(09): 143148. doi: https://doi.org/10.20546/ijcmas.2020.909.017 